Pak. j. sci. ind. res. Ser. B: biol. sci. 201558 (3) 122-125

\title{
Effect of Integrated Nutrient Application on Growth and Yield of Maize
}

\author{
Muhammad Abid ${ }^{a}$, Riaz Ahmed ${ }^{b}$, Adnan Umair*c and Muhammad Islam ${ }^{\text {d }}$ \\ ${ }^{a}$ Directorate of Soil and Water Conservation, Rawalpindi, Pakistan \\ ${ }^{b}$ Department of Agronomy, University of Agriculture Faisalabad, Pakistan \\ ${ }^{\mathrm{c}}$ Soil and Water Conservation Research Station Sohawa, Jhelum, Pakistan \\ ${ }^{\mathrm{d}}$ National Fertilizer Development Centre, Islamabad, Pakistan
}

(received April 11, 2014; revised October 29, 2015; accepted October 31, 2015)

\begin{abstract}
Abstact. Comparative effect of organic and inorganic fertilizer on the growth and yield of maize variety Hicorn-984 was studied at agronomic research area of University of Agriculture, Faisalabad during the year 2005. The trial was laid out according to randomised complete block design in triplicate and plot size was $3 \mathrm{~m} \times 6 \mathrm{~m}$. There were six treatments comprising of various levels of organic and inorganic fertilizer in different combinations and a control. Combined application of organic and inorganic fertilizer differed significantly from control as well as from their sole application. Comparison of treatments showed that inorganic fertilizer application at the rate of $70-50-35 \mathrm{~kg} \mathrm{NPK} /$ ha along with $5 \mathrm{t} /$ /ha poultry manure showed maximum plant growth parameters such as leaf area $\left(1537 \mathrm{~cm}^{2}\right)$, plant height $(195 \mathrm{~cm})$, number of grains per cob (452) and thousand grain weight (234 g) which were at par with $\mathrm{T}_{5}(70-50-35 \mathrm{~kg} \mathrm{NPK} / \mathrm{ha}$ along with $8 \mathrm{t} / \mathrm{ha}$ FYM) but significantly higher than the treatments where organic manures and inorganic fertilizers were applied separately. Maximum grain yield (5.7 t/ha) and cost-benefit ratio (1.7) were achieved in the treatment $\mathrm{T}_{6}$ (NPK at 70-50-35 kg/ha along with $5 \mathrm{t} /$ ha poultry manure) while, minimum grain yield $(2.3 \mathrm{t} / \mathrm{ha})$ and cost benefit ratios (1.1) were recorded in control. Combined application of organic and inorganic fertilizer results in increase in yield and profitability to farmer as compared to their sole application.
\end{abstract}

Keywords: farm yard manure, inorganic fertilizers, maize, nitrogen, poultry manures, yield components

\section{Introduction}

Maize is an important food and feed cereal crop in the world and is a staple food for more than 1.2 billion people in Sub-Saharan Africa and Latin America. Worldwide production of maize is 785 million tonnes and annual consumption by humans is 116 million tonnes with maximum consumption per capita of $174 \mathrm{~kg} / \mathrm{year}$ in Lesotho, Eastern and Southern Africa uses $85 \%$ of their production as food, while Africa as a whole uses $95 \%$ of its production (IITA, 2009). In Pakistan, maize is grown on an area of 1087 thousand hectares with an annual grain production of 4338 thousand tonnes and average grain yield is about $3991 \mathrm{~kg} / \mathrm{ha}$ (GoP, 2012-2013). Maize occupies $4.8 \%$ of the cropped area and contributes $3.5 \%$ of the values of agricultural outputs.

Average maize yield in Pakistan is much lower than developed countries of the world because imbalanced fertilizer use, soil nutrient depletion and poor crop husbandry practices. According to a report of NFDC (2008), there is a negative nutrient balance of approximately -472.99 for

*Author for correspondence; E-mail: adnanumair@gmail.com
$\mathrm{N},-313.14$ for $\mathrm{P}, 00-3707.33$ for $\mathrm{K}$ and -4493.46 for total nutrients in most of the soils of Pakistan. Organic manures and inorganic fertilizers together are of great importance for agricultural sustainability, soil productivity as well as for soil properties (Saha et al., 2008). The use of inorganic fertilizers to restore the fertility of the soil has not been effective because of high leaching, continued exports of nutrients through crop harvest and unbalanced mineral contents in the soil (Kone et al., 2013). However, integrated use of organic and inorganic manures seems to be an approach for sustainable production of crops (Rong et al., 2001). It improves the efficiency of the chemical fertilizers and thus may reduce their use (Hill, 2007). Integrated use of organic inputs such as crop residues, manures and compost has great potential for improving soil productivity and crop yield through the improvement of physical, chemical and microbiological properties of the soil as well as nutrient supply (Shah et al., 2009). Nutrients contained in organic matter are released slowly and are available for a longer time in the soil, thereby ensuring long residual effects (Arancon et al., 2004). The use of organic fertilizers together with chemical fertilizers, compared to the addition 
of organic fertilizers alone, has a higher positive effect on microbial biomass and hence soil health (Dutta et al., 2003).

Organic farming reduces the soil acidity, $\mathrm{pH}$ and cost of production. It also makes the best use of local wastes i.e. dung, urine, crop residues, kitchen and industry wastes etc. as a low cost substitute of the artificial fertilizers. A combination of organic manure and chemical fertilizer results in consistent availability of $\mathrm{NO}_{3}$ during the growing season of the crop (Nyiraneza and Snapp, 2007). However, when farming continues on the same site for several years, residual effects of fertilizer treatments may considerably affect soil chemical properties and consequently crop yield. Due to their residual value that could last for several years of cropping, organic amendments can be intermittently applied to soils and supplemented by chemical fertilizers to rapidly supply immediate nutrients required by crop plants (Kihanda et al., 2006). Keeping in view, the significance of organic and inorganic manures, the present study was conducted to evaluate the effect of organic matter and inorganic fertilizers separately and in combination at different levels for improving the growth and yield of maize under irrigated conditions.

\section{Materials and Methods}

A field experiment was conducted using hybrid maize variety Hicorn-984 at the agronomic research area University of Agriculture Faisalabad, Pakistan during the year 2005. Soil of experimental site was non saline, non sodic and non calcareous, sandy clay loam (Table 1).

The trial was laid out according to randomized complete block design (plot size of $6 \times 3 \mathrm{~m}^{2}$ ). There were six treatments as described below.

Table 1. Texture of experimental site

\begin{tabular}{ll}
\hline \hline Characteristics & Value \\
\hline Sand & $54.07 \%$ \\
Silt & $20.48 \%$ \\
Clay & $25.45 \%$ \\
Textural class & Sandy clay loam \\
Organic matter & $0.65 \%$ \\
Saturation percentage & $35.8 \%$ \\
ECe & $1.80 \mathrm{~d} / \mathrm{Sm}$ \\
pH & 7.6 \\
Total nitrogen & $0.07 \%$ \\
Extractable potassium & $180 \mathrm{ppm}$ \\
Available phosphorus & $7.80 \mathrm{ppm}$
\end{tabular}

$\mathrm{T}_{1}=$ Control; $\mathrm{T}_{2}=120-85-60 \mathrm{~kg} \mathrm{~N}, \mathrm{P}_{2} \mathrm{O}_{5}$ and $\mathrm{K}_{2} \mathrm{O} / \mathrm{ha}$; $\mathrm{T}_{3}=14 \mathrm{t} / \mathrm{ha} \mathrm{FYM} ; \mathrm{T}_{4}=8 \mathrm{t} /$ ha poultry manure; $\mathrm{T}_{5}=70-50-$ $35 \mathrm{~kg} \mathrm{~N}, \mathrm{P}_{2} \mathrm{O}_{5}$ and $\mathrm{K}_{2} \mathrm{O} / \mathrm{ha}+8$ t/ha FYM; $\mathrm{T}_{6}=70-50-35$ $\mathrm{kg} \mathrm{N}, \mathrm{P}_{2} \mathrm{O}_{5}$ and $\mathrm{K}_{2} \mathrm{O} / \mathrm{ha}+5$ t/ha poultry manure.

Whole amounts of well decomposed organic manures and inorganic $(1 / 3 \mathrm{~N}, \mathrm{P}$ and $\mathrm{K})$ fertilizers were applied as basal dose. Second dose of $\mathrm{N}$ was applied at knee height and the $3^{\text {rd }}$ dose at tesseling stage of the crop. Nitrogen was applied in the form of urea, $\mathrm{P}$ in the form of diammonium phosphate (DAP) and $\mathrm{K}$ in the form of sulphate of potash. The organic materials used in the experiment were analysed for their crop nutrition value. The poultry and farm yard manure used in the experiment contained $1.75,0.65,1.07$ and $0.26,0.5,0.56 \% \mathrm{~N}, \mathrm{P}$ and $\mathrm{K}$, respectively.

All the treatments were replicated three times. The seed rate of $30 \mathrm{~kg}$ was used and a plant population of 60000 plants per hectare was maintained by thinning the crop at $20 \mathrm{~cm}$ plant-plant distance. Row to row distance of $70 \mathrm{~cm}$. Recommended cultural practices for the crop were carried throughout the study. Quantity of fertilizers and organic manures to be applied in the plots was calculated by the formula:

$$
(\mathrm{R} \times \mathrm{A} \times 100) /(10,000 \times \mathrm{C})
$$

where:

$\mathrm{R}=$ Rate of fertilizer to be applied $(\mathrm{kg} / \mathrm{ha}) ; \mathrm{A}=$ area of plot $\left(\mathrm{m}^{2}\right) ; \mathrm{C}=$ concentration of element in the source $(\%) ; 10,000=$ hectare area $\left(\mathrm{m}^{2}\right)$.

Leaf area was measured fortnightly by placing $10 \mathrm{~g}$ sample on leaf area meter and plant height and yield was recorded at maturity. Data on all observations were subjected to analysis of variance (ANOVA) by using software MSTATC. Treatment means were compared by least significant difference (LSD) test (Steel et al., 1997). Correlation analysis was also done to study the strength of relation between parameters.

\section{Results and Discussion}

Growth parameters. Analysis of variance indicated that the leaf area and plant height were significantly influenced by the use of different sources of nutrients (Table 2). Maximum leaf area $\left(1537 \mathrm{~cm}^{2}\right)$ and maximum plant height $(195 \mathrm{~cm})$ were found in the treatment where inorganic fertilizers along with PM $\left(\mathrm{T}_{6}\right)$ was applied while, the minimum leaf area $\left(1081 \mathrm{~cm}^{2}\right)$ and plant height $(121 \mathrm{~cm})$ were recorded in the control. The analysis showed that the root/shoot ratios ranged between 
0.32 for $\mathrm{T}_{6}$ to 0.68 for control. Significantly higher root/shoot ratios were recorded at low rates of soil nutrient application than the higher rates (Table 2). It has been observed that, root growth is very sensitive to nutrient supply and nutrient supply can significantly alter root shoot ratio and nutritional stress in corn plant can cause significant modification in root morphology for efficient uptake (Kimberley and Lindquist, 2009; Zhang, 1995). Comparison of treatment means showed that application of different treatments resulted in higher grain protein content than that of the control. Maximum grain protein content $(10 \%)$ were recorded in the treatment $\mathrm{T}_{6}$ and $\mathrm{T}_{5}$. Combined application of organic and inorganic manures results more nitrogen uptake by crop which is the source of protein formation in the cereals (Table 2).

Yield parameters. Data regarding yield related parameters reflect that application of different sources of nutrients had a significant effect on the grain and dry matter yield of the maize. The highest grain and dry matter yield ( $5.7 \mathrm{t} / \mathrm{ha}$ and $10.4 \mathrm{t} / \mathrm{ha}$ ) was recorded in $\mathrm{T}_{6}$ followed by $\mathrm{T}_{5}$ (Table 3). Application of PM along with inorganic fertilizers also significantly improved 1000 grain weight and number of grain per cob (Table 3). These results are similar to the studies of Shilpashree et al. (2012), who observed a significant increase in grain and stover yield of maize due to combined application of organic and inorganic fertilizers mainly as a result of increase in growth rate due to ready availability of nutrient. Plant harvest index is the ratio of economic yield to total plant biomass of the crop (Hay, 1995). Harvest index reflects the partitioning of photosynthates between the grains and the vegetative plant growth. Improvements in harvest index emphasize the importance of carbon allocation in grain production. Highest harvest index (0.6) has been observed in the treatments where FYM and PM were applied in combination with inorganic fertilizer. Shah et al. (2009) pointed out that it might be due to the timely availability of $\mathrm{N}$ and increase in water holding capacity of soil. The results showed that benefit cost ratio increased by increasing application of nutrients to soil. Its value ranged between 1.1-1.7. The basic inputs such as seed, land preparation, sowing, inter-tillage, irrigation, plant protection, weed control and harvesting contributed to cost of production at the same level for all the treatments. Minimum benefit cost ratio (1.1) was obtained in control (Table 3) where, fertilizers and organic manures were not applied and benefit cost ratio increased to 1.7 for $\mathrm{T}_{6}$ (NPK at $70-50-35 \mathrm{~kg} / \mathrm{ha}+5$ t/ha poultry manure). These results are also in conformity with the findings of Cheema et al. (2010), who conducted experiment under similar soil and climatic conditions.

Table 2. Effect of different organic and inorganic fertilizer leaf area, plant height, root shoot ratio, number of grains per cob and grain protein content of maize

\begin{tabular}{llllll}
\hline \hline Treatments & $\begin{array}{l}\text { Leaf area } \\
\left(\mathrm{cm}^{2}\right)\end{array}$ & $\begin{array}{l}\text { Plant height } \\
(\mathrm{cm})\end{array}$ & $\begin{array}{l}\text { Root shoot } \\
\text { ratio }\end{array}$ & $\begin{array}{l}\text { Number of } \\
\text { grains per cob }\end{array}$ & $\begin{array}{l}\text { Grain protein } \\
\text { content }\end{array}$ \\
\hline $\mathrm{T}_{1}($ Control $)$ & $1082 \mathrm{e}$ & $121 \mathrm{c}$ & $0.7 \mathrm{a}$ & $252 \mathrm{c}$ & $9.2 \mathrm{~d}$ \\
$\mathrm{~T}_{2}(120-85-60 \mathrm{~kg} \mathrm{NPK} / \mathrm{ha})$ & $1390 \mathrm{c}$ & $173 \mathrm{~b}$ & $0.4 \mathrm{bc}$ & $424 \mathrm{ab}$ & $9.6 \mathrm{~b}$ \\
$\mathrm{~T}_{3}(14 \mathrm{t} /$ ha FYM $)$ & $1255 \mathrm{~d}$ & $183 \mathrm{~b}$ & $0.5 \mathrm{~b}$ & $373 \mathrm{~b}$ & $9.4 \mathrm{c}$ \\
$\mathrm{T}_{4}(8 \mathrm{t} /$ ha poultry manure $)$ & $1373 \mathrm{c}$ & $178 \mathrm{ab}$ & $0.5 \mathrm{~b}$ & $406 \mathrm{ab}$ & $9.6 \mathrm{~b}$ \\
$\mathrm{~T}_{5}(70-50-35 \mathrm{~kg} \mathrm{NPK} / \mathrm{ha}+8 \mathrm{t} /$ ha FYM $)$ & $1475 \mathrm{~b}$ & $190 \mathrm{a}$ & $0.4 \mathrm{bc}$ & $445 \mathrm{a}$ & $10.0 \mathrm{a}$ \\
$\mathrm{T}_{6}(70-50-35 \mathrm{~kg} \mathrm{NPK} / \mathrm{ha}+5 \mathrm{t} /$ ha poultry manure $)$ & $1537 \mathrm{a}$ & $195 \mathrm{a}$ & $0.3 \mathrm{c}$ & $452 \mathrm{a}$ & $10.0 \mathrm{a}$ \\
\hline \hline
\end{tabular}

Means followed by different letters in the same column differ significantly (p 0.05$)$ as determined by LSD test.

Table 3. Effect of different organic and inorganic fertilizers on grain yield and yield attributes of maize

\begin{tabular}{llllll}
\hline \hline Treatments & $\begin{array}{l}\text { Dry matter } \\
\text { yield }(\mathrm{t} / \mathrm{ha})\end{array}$ & $\begin{array}{l}1000 \text { grain } \\
\text { weight }(\mathrm{g})\end{array}$ & $\begin{array}{l}\text { Grain yield } \\
(\mathrm{t} / \mathrm{ha})\end{array}$ & $\begin{array}{l}\text { Harvest } \\
\text { index }\end{array}$ & $\begin{array}{l}\text { Benefit cost } \\
\text { ratio }\end{array}$ \\
\hline $\mathrm{T}_{1}($ Control $)$ & $6.8 \mathrm{e}$ & $160 \mathrm{e}$ & $2.3 \mathrm{c}$ & $0.4 \mathrm{c}$ & 1.1 \\
$\mathrm{~T}_{2}(120-85-60 \mathrm{~kg} \mathrm{NPK} / \mathrm{ha})$ & $9.7 \mathrm{c}$ & $219 \mathrm{~b}$ & $5.4 \mathrm{a}$ & $0.6 \mathrm{a}$ & 1.3 \\
$\mathrm{~T}_{3}(14 \mathrm{t} / \mathrm{ha} \mathrm{FYM})$ & $9.5 \mathrm{c}$ & $186 \mathrm{~d}$ & $4.1 \mathrm{~b}$ & $0.5 \mathrm{~b}$ & 1.6 \\
$\mathrm{~T}_{4}(8 \mathrm{t} /$ ha poultry manure $)$ & $9.2 \mathrm{~d}$ & $210 \mathrm{c}$ & $4.4 \mathrm{~b}$ & $0.5 \mathrm{~b}$ & 1.6 \\
$\mathrm{~T}_{5}(70-50-35 \mathrm{~kg} \mathrm{NPK} / \mathrm{ha}+8 \mathrm{t} /$ ha FYM $)$ & $10.1 \mathrm{~b}$ & $231 \mathrm{a}$ & $5.5 \mathrm{a}$ & $0.6 \mathrm{a}$ & 1.7 \\
$\mathrm{~T}_{6}(70-50-35 \mathrm{~kg} \mathrm{NPK} / \mathrm{ha}+5 \mathrm{t} /$ ha poultry manure $)$ & $10.4 \mathrm{a}$ & $234 \mathrm{a}$ & $5.7 \mathrm{a}$ & $0.6 \mathrm{a}$ & 1.7 \\
\hline \hline
\end{tabular}

Means followed by different letters in the same column differ significantly (p 0.05 ) as determined by LSD test. 


\section{Conclusion}

It may be inferred from the present study, that higher growth and yield parameters of the maize crop under the existing conditions may be achieved by applying inorganic fertilizers NPK at 70-50-35 kg/ha along with $5 \mathrm{t} / \mathrm{ha}$ poultry manure or $8 \mathrm{t} / \mathrm{h}$ a farmyard manure. Combined application of the organic and inorganic fertilizers may result in higher benefit cost ratio than their sole application.

\section{References}

Arancon, N.Q., Edwards, C.A., Atiyeh, R., Metzger, J.D. 2004. Effects of vermicomposts produced from food wastes on the growth and yields of greenhouse peppers. Bioresources Technology, 93: 139-144.

Cheema, M.A., Farhad, M.F., Saleem, H.Z., Khan, A., Munir, M.A., Wahid, F., Hammad, H.M. 2010. Nitrogen management strategies for sustainable maize production. Crop Environment, 1: 49-52.

Dutta, S., Pal, R., Chakeraborty, A., Chakrabarti, K. 2003. Influence of integrated plant nutrient phosphorus and sugarcane and sugar yields. Field Crop Research, 77:43-49.

GoP, 2013. Pakistan Economic Survey 2012-13. Ministry of Finance, Government of Pakistan. Islamabad, Pakistan.

Hay, R.K.M. 1995. Harvest index: A review of its use in plant breeding and crop physiology. Annals of Applied Biology, 126: 197 - 216.

Hill, J.H. 2007. How a corn plant develops. Iowa State University of Science and Technology. Cooperative extension service Ames. Iowa. 641: 923-2856.

IITA, 2009. Annual Report, 2009. International Institute of Tropical Agriculture, PMB 5320, Ibadan, Oyo State, Nigeria. www.iita.org/maize, jsessionid

Khan, S., Khalil, S.K. 2014. Integrated use of organic and inorganic fertilizers in wheat and their residual effect on subsequent mung bean. International Journal of Farming and Allied Sciences, 3: 835-844.

Kihanda, F.M., Warren, G.P., Micheni, A.N. 2006. Effect of manure application on crop yield and soil chemical properties in a long-term field trial of semi-arid Kenya. Nutrient Cycling Agroecosystems,
76: $341-354$

Kimberly, D.B., Lindquist, J.L. 2009. Effects of nitrogen supply on the root morphology of corn and velvetleaf. Journal of Plant Nutrition, 32: 1371-1382.

Kone, B., Amadji, GL., Touré, A., Mariko, M., Huat, J. 2013. A case of Cyperus spp. and Imperata cylindrica occurrences on acrisol of the Dahomey gap in South Benin as affected by soil characteristics: A strategy for soil and weed management. Applied and Environmental Soil Science, 2013: 1-7.

NFDC, 2008. Fertilizer Use Survey, 2007-2008, National Fertilizer Development Centre, Planning and Development Division, Islamabad, Pakistan.

Nyiraneza, J., Snapp, S. 2007. Integrated management of inorganic and organic nitrogen and efficiency in potato systems. Soil Science Society of America Journal, 71: 1508-1515.

Xiang, R.M., Jiang, J.R., Zhu, M.H., Liu, Q., Zhang, F.Q., Liu, J.M. Yue, Z.H. 2001. Effects of application of inorganic fertilizer in combination with organic fertilizer to red upland soil. Chinese Journal of Hunan Agricultural University, 27: 453-456.

Saha, S., Mina, B., Gopinath, K.A., Kundu, S., Gupta, H.S. 2008. Organic amendments affect biochemical properties of a subtemperate soil of the Indian Himalayas. Nutrient Cycle in Agroecosystem, 80: 233-242.

Shah, S.T.H., Shahid, I.Z., Waseem, M., Asghar, A., Tahir, M., Waleed, B.K. 2009. Growth and yield response of maize (Zea mays L.) to organic and inorganic sources of nitrogen. Pakistan Journal of Life and Social Sciences, 7: 108-111.

Shilpashree, V.M., Chidanandappa, H.M., Jayaprakash, R., Punitha, B.C. 2012. Influence of integrated nutrient management practices on productivity of maize crop. Indian Journal of Fundamental and Applied Life Science, 2: 45-50.

Steel, R.G.D., Torrie, J.H., Dickey, D. 1997. Principles and Procedure of Statistics. A Biometrical Approach, pp. 352-358, ${ }^{\text {rd }}$ edition, McGraw Hill Book Co. Inc., New York, USA.

Zhang, D.Y. 1995. Analysis of growth redundancy of crop root system in semi-arid area. Acta Botanica Boreali-Occidentalia Sinaca, 15: 110-114. 